\title{
Improving Students' Reading Comprehension Achievement by Using K-W-L Strategy
}

\author{
Erika Sinambela $^{1}$, Sondang Manik ${ }^{1} \&$ Rotua Elfrida Pangaribuan ${ }^{1}$ \\ ${ }^{1}$ English Department, Language and Arts Faculty, HKBP Nommensen University, Medan North Sumatra, Indonesia \\ Correspondence: Sondang Manik, English Department Language and Arts Faculty, HKBP Nommensen University, \\ Medan North Sumatra, Indonesia. Jl.Sutomo no 4A - Medan (20234) - North Sumatra - Indonesia. Tel: \\ 61-452-2922, 414-5411.E-mail: erika_sinambela@yahoo.com
}

Received: June 25, 2015

Accepted: June 13, 2015

Online Published: July 23, 2015

doi:10.5430/elr.v4n3p13

URL: http://dx.doi.org/10.5430/elr.v4n3p13

\begin{abstract}
The research is done in order to improve students' reading comprehension achievement. The writer uses KnowWant-Learn (KWL) strategy, and the data are obtained from the experimental group and the score of the control group, from the fifth semester students of English department, Faculty of Education of HKBP Nommensen University Medan. The data were analyzed by applying t-test formula and it was found that students' achievement who were taught by applying KWL was higher than those who were taught without applying KWL. The data obtained that the ability of fifth semester students were taught by KWL is better and effective in the experimental group, than the score of the control group .It was found that students' achievement who were taught by applying KWL was higher than those who were taught without applying KWL. When doing treatment in four meetings to the experimental group the students were active and the score in the post-test of the test, they got higher than score in the pre-test. The researcher thought that, if KWL used in teaching reading more than fourth, it would increase the students' reading comprehension. It means that the application of KWL strategy significantly affects on students' reading comprehension The mean score of the students who were taught by applying KWL strategy is 73,36 it is higher than mean score of students who were tauhgt without applying K-W-L is 68,73 , The $\mathrm{t}_{\text {observed }}(3,56)$ is higher than $t_{\text {table }}(1,992)$ at the level of significance of 0,05 of two-tailed test. It mens that $H_{a}$ is accepted. Thus, it can be concluded that there is a significant effect on students' reading comprehension achievement.
\end{abstract}

Keywords: Know - Want - Learn technique (K-W-L), Reading comprehension

\section{Introduction}

There are four language skills in English, they are: listening, speaking, reading and writing. Listening competence is universally 'larger' than speaking competence. It is any wonder, that in recent years the language teaching profession has placed a concerted emphasis on listening comprehension. Speaking and listening skills are closely intertwined. The interaction between these two models of performance is applied especially to conversation, the most popular discourse category in the profession. Reading is also one of the most important skills in learning a language besides listening, speaking and writing (Kustaryo 1988). It is certainly not easy to present the English reading to Indonesian students whose language system is different. Reading in their own language is much easier than that of the language learned because they have mastered the vocabulary and the structure of their own. As reading plays an important role in language learning, it would be better that this teaching is wisely done. To understand a text students must have a good command of the vocabulary of the target language. The reader uses knowledge, skills and strategies to determine what the text meaning is. Writing is an act of discovery, of communication, of joy. It connects us to work, to culture, to society, to existing knowledge, and to the meanings of our lives.

It was found that students' ability in reading was still low. The students faced many difficulties in reading texts. They often failed in reading texts because of lack of vocabularies and technique in reading. The problem also comes from the teacher's technique and strategy in teaching. During the writer's observation, she found that the teacher still applied a traditional method, the teachers asked the students to write things in their exercise books freely, read the texts by heart and opened dictionary anytime they stuck on using words that they didn't know. It caused the students bored and did not have a concentration in learning so, they could not gain the purpose of reading. 
To overcome this problem, it is advisable that the teacher changes their strategy in the teaching process and should consider the most effective and creative language teaching strategy in teaching reading skill. A teacher is one the most influencing factor in obtaining the success of learning English. An Approach may be the solution to improve the teaching process. Approach is a correlative assumptions dealing with the nature of language teaching and learning. In doing their profession as an educator a teacher always gives the best for their student.

The aim of teaching reading is to develop the students reading skill so that they can read English text effectively and efficiently. To be able to read effectively and efficiently student should have a particular purpose in their mind before they interact with the text. The main purpose of reading a text is to comprehend and obtain much information. To understand a text a student must have a good command of vocabulary of the target language but it does not mean merely learning the words. Many students find some difficulties when they are reading.

Most of the students are passive in the class and they felt that learning reading comprehension is boring. The writer thought that the reason why they got bored in learning the reading was because of the teaching strategy. The teacher must choose the suitable strategy to make the process of teaching reading comprehension running well. The writer learned that to improve the students' reading comprehension is by choosing the appropriate strategy that is by using K-W-L (Know-Want-Learn) strategy. The writer thinks that K-W-L strategy can help the teacher to improve the students' achievement in reading comprehension.

Based on the student's problem in teaching and learning process, especially in reading comprehension, the writer hopes that by using K-W-L (Know-Want-Learn), the students could comprehend the text easier.

\subsection{The Objective of the study}

The objectives of this study are:

1) to find out how the KWL technique significantly improve the students reading comprehension.

2) to identify how good the students' reading comprehension of the fifth semester students of Faculty of Education is.

\subsection{The Scope of the Study}

This study is focused on improving the students' achievement in reading expository text by using Know-Want-learn (K-W-L) technique and was done with the fifth semester students of Faculty of Education of HKBP Nommensen University Medan.

It is hoped that the result of the study will be significant for:

1) the writer, to improve her teaching skill in reading subject.

2) English teachers, to use KWL as one of some strategies to improve their teaching

3) students of HKBP Nommensen University, to motivate them to take this strategy when they are facing with reading material.

4) For further research.

This study is planned to investigate the improvement of Know-Want-Learn (KWL) on the students' reading comprehension. In conducting a research, theories are needed to explain some context or terms applied in the research concerned. Theoretical framework of this research are presented and discussed as the following.

\section{1) Reading}

Reading is one of the most important skills in learning a language besides listening, speaking and writing. The fundamental goal for any reading activity is knowing enough science concepts and knowing the language. To Indonesian students this is a bridge to understand scientific books that they read. As they lack knowledge of English they often encounter difficulties when reading their compulsory books written in that language (Kustaryo 1988). Reading is a thinking process. The act of recognizing word requires interpretation of graphic symbols (Burns 1984: 10). Reading may be defined as the meaningful interpretation of printed and written verbal symbols. For the beginner, reading is concerned mainly with learning to recognize the printed symbols that represent language and to respond intellectually and emotionally when being asked about the content of the text he has read. The reasoning side of reading becomes increasingly important as word recognition is mastered. As proficiency in reading increases, individuals learn to adapt their reading strategies in accordance with the purpose for reading and the restriction imposed by the material. The nature of reading task, therefore, changes a learner's progress to the more nature levels (Albert J. Harris \& Edward R. Sipay p.13) 
The definitions of reading above can be concluded that reading is one of skills in English which is needed in the process to interpretation of graphic symbols and written symbols. We can give respond about the content of reading materials we has read, we are also can get the message from the reading materials.

\section{2) The Purposes of Reading}

When we begin to read, we actually have a number of initial decisions to make, and we usually make these decisions very quickly, almost unconsciously in most cases. Most of people read for general comprehension. Here we might read a novel, short story, a newspaper article or a report of some type to understand the information in the text, to be entertained and to use the information for a particular purpose. Cadlin and Hall (2002:13) states that there are seven purposes of reading, they are:

\section{3) Reading to search for simple information and reading to skim}

Reading to search for simple information is a common reading ability, through some researchers see it as a relatively independent cognitive process. It is use so often in reading tasks that it is probably best seen as a type of reading ability. In reading to search, we typically scan the text for a specific piece or information or a specific word. It involves, in essence, a combination of strategies for guessing where important information might be in the text, and then using basic reading comprehension skills on those segments of the text until a general idea is formed.

\section{4) Reading to learn for texts}

Reading to learn typically occurs in academic and professional contexts in which a person needs to learn a considerable amount of information from a text. Reading to learn is usually carried out at a reading rate somewhat slower than general reading comprehension. In addition, make stronger inference demands than general comprehension to connect text information with background knowledge.

\section{5) Reading to integrate information, write and critique texts}

Reading to integrate information requires additional decisions about the relative importance of complementary, mutually supporting or conflicting information and the likely restructuring of a theoretical frame to accommodate information from multiple sources. Both reading to write and reading to critique texts may be task variants of reading to integrate information.

\section{6) Reading for general information}

The notion of general reading comprehension has been intentionally saved for the last in this discussion for two reasons. First, it is the most basic purpose for reading, underlying and supporting most other purpose for reading. Second, general reading comprehension is actually more complex than commonly assumed. Reading for general comprehension when accomplished by a skilled fluent reader, requires very rapid and automatic processing of words, strong skills in informing a general meaning representation of main ideas, and efficient coordination of many processes under very limited time constraints.

The purpose of reading above can be concluded that reading is used to search information, to write and to give any critique about the contents of the text or reading materials.

\section{7) Teaching}

Teaching is a part of education. Teaching is an activity to make interaction between teacher and the students. In teaching process the students must be active to develop their knowledge and to achieve their purpose. The teaching process does not depend on the students (student centered) but the teaching as a process is directed to the goal oriented from students and teacher.

In a teaching process, a teacher needs to create a purpose clearly. A teacher should be involved in the process of teaching, such as: planning, collecting sources, giving motivation, giving a help, and improve some errors to reach the purpose of their teaching.

\section{8) Reading Comprehension}

Reading with comprehension means understanding what has been read. Comprehension involves understanding the vocabulary seeing the relationship among words and concepts, organizing idea, recognizing authors' purpose, making judgment and evaluating. Word important factor in determining the degree of comprehension.

According to Heilman $(1981 ; 265)$ reading is a process of making sense of written ideas through meaningful interpretation interaction with language. A good reader is one who understands what he reads, and the faster he able to get meaning from his reading the more efficient he is. The rate of comprehension needs to be adjusted to the 
purpose of reading skills, and like skill development in any area, reading rate can be improved with training and with practice.

From the statement, it is clearly stated that comprehension or understanding in every reading activity is an important part of skill learning. The student must be able to read a text consisting of many sentences and select the main idea to which all the sentences refer. After the reader is able to comprehend what the most important thought is, he needs to be able to identify the details that support the main idea. He must think about what he reads in order to interpret meaning as well as to get the factual information given.

\section{9) Levels of Reading}

According to Burns $(1984 ; 177)$, there are four levels of reading comprehension. The following levels of comprehension can tell us about how far the students understand about reading material and which level has been achieved.

\section{(1) Literal Comprehension}

Literal comprehension involves acquiring information that is directly stated, the basic of literal comprehension is recognizing stated the main idea, detailed caused effect and sequence. It is also prerequisite for higher-level understanding. The important in this level is understanding of vocabulary, sentence meaning, and paragraph meaning.

\section{(2) Interpretative Comprehension}

Interpretative comprehension involves reading between the lines or making inferences. It is the process of deriving ideas that are implied rather than directly stated. Skills for interpretative reading include:

1. Inferring main ideas of passages in which the main ideas are not directly stated

2. Inferring cause-effect relationships when they are not directly stated

3. Inferring referents of pronouns

4. Inferring referent of adverbs

5. Inferring omitted words

6. Detecting mood

7. Detecting the author's purpose in writing

8. Drawing conclusion.

\section{(3) Critical Comprehension}

Critical comprehension is evaluating written material comparing the ideas discovered in the material with known standards and drawing conclusion about their accuracy, appropriateness, and timeliness. The critical reader must be an active reader, questioning, searching for facts, and suspending judgment until he or she has considered all of the material. Critical reading depends upon literal comprehension, and grasping implied ideas is especially important.

\section{(4) Creative Comprehension}

Creative comprehension involves going beyond the material presented by the author. It requires reader to think as they read, just as critical reading does and it also requires them to use their imaginations. Through creative reading the reader creates something new idea, the solution to a problem, a new way of looking at something from the ideas gleaned from the text.

\section{0) The Weakness of students in reading skill}

The weaknesses of students in reading skills are unquestionable. They lack prior knowledge, which is a very important foundation in getting the gist of the paragraph. KustaryoSukirah $(1988 ; 15)$, reading comprehension problem with the paragraph involves some closely related phenomena; the lacks prior knowledge such as:

\section{(1) Word Recognition}

Word Recognition is an important component in understanding target language or native language. Students face difficulties when trying to recognize words of the target language. These difficulties arise because these two languages, English and Indonesia, are not nor branches of the same language and English words are complex 


\section{(2) New word recognition}

New word and words that have been learned are two aspects that might cause difficulties in the learning vocabulary. Learning new words, words that are introduced for the first time to the students is greatly influenced by their prior knowledge about words.

\section{(3) The Language system}

The language system involves vocabulary and structure, vocabulary and structure and sound system, and vocabulary and spelling. Vocabulary and structure are firmly tied; they cannot be separated from each other. In the beginning classes it is essential that students know the differences among the form in the target language and that they understand the role played by the different element in sentences. They should use only items that can be grammatically employed, because knowing the meaning of a word from a dictionary does not ensure the correct use of the word in a particular context.

Understanding the sound system of the target language is one of the aspects of learning language that should not be ignored. Besides stress, intonation is also an important aspect of learning language. Intonation has a particular meaning, and each language has its own intonation patterns, and often dialects within a given language are characterized by their intonation pattern. English spelling is difficult for the students because many cases of phonemic irregulation or lack of a phoneme correspondence. Some students only to overcome these problems by consult the dictionary continuously.

\section{(4) Other factor}

Other factors that might weaken the students when learning a language are the student himself, the teacher, and the educational context.

\section{a. The students}

One of the factors that influence the student when learning a language is the student himself. The students attitude toward the target language should be positive or should always concentrate on the language learned

Motivation is also an aspect that is not less important in learning a language than attitude. Motivation goes hand in hand with attitude to reach the target language. These two aspects, motivation and attitude influence the success or the failure of students' study.

\section{b. The teacher}

The teacher of course, is important in learning situation. The teacher skill and personality are instrument that create the condition for learning. The teacher skill depends on both his language proficiency and his knowledge of methods and techniques of language teaching.

The teacher is the principal model for the student; the teacher should be well trained to apply suitable materials that he has to present in the classroom. The teacher should choose appropriate methods and technique to make his teaching interesting.

\section{1) K-W-L (Know-Want-Learn)}

David. C $(1979 ; 11)$ stated that K-W-L is a strategy that models the active thinking needed when reading expository text. The letters K-W-L stand for three activities students engage in when reading to learn; recalling what they KNOW, determining what they WANT to learn, and identifying what they LEARN as they read.

The teacher asks students to brainstorm what they know about a given topic and writes their ideas on the board or worksheet that can be saved. The point of the exercise is to generate curiosity, so it helps to list as many ideas as time allows; pausing to encourage the more reticent students to contribute involves as many as possible. Then the teacher ask, "what do you wan to know?" students then suggest a new list for the board, this time with question marks. The goal of this step is to demonstrate to students the importance of asking questions of the material before reading. These lists become a reference for the last question which comes up later:" what have you learned that is new and what do you still want to learn?"

K-W-L not only helps the teacher assess the students' levels of understanding, but also models the learning process and activates thinking on the topic. This strategy is designed to help students develop a more active approach to reading expository material. Teacher first model and stimulate the kinds of thinking needed for learning and then give students individual opportunities to list what they know, what questions they want to answer, and what they have learned from reading the text. 
This strategy has been shown to be an effective tool to help students become more active thinkers and to help them remember better communicate the active nature of reading in-group setting. This strategy is designed for group instruction and can be used with either whole classes or smaller groups. It can be used in all curricular areas and at all grades in which students are reading expository material.

KWL strategy is used as an organizational framework from which to begin the study of the coursework. Through the explicit outline students create for themselves, they will anticipate new infromation, relate it to what they know or want and formulate new questions. It helps students monitor their own learning and understanding of concepts.

\section{2) The Purposes of the K-W-L Technique:}

There are some purposes of K-W-L technique namely:

1. Elicits students' prior knowledge of the topic of the text

2. Sets a purpose for reading

3. Help students to monitor their comprehension

4. Constructs meaning from what they read

5. Allows the students to assess their comprehension of the text

1. Provides an opportunity for students to expand ideas beyond the text.

\section{3) How to use the K-W-L Technique}

The procedure of using K-W-L technique is described as the following:

1. Choose one of the reading texts

2. Create a KWL chart. The teachers create a chart on whiteboard on an overhead transparency. In addition, the students should create chart on which to record information.

3. Ask the students to brainstorm words, terms, or phrases they associate with a topic. The teacher and the students record these associations in the $\mathrm{K}$ column of their charts. This is done until students run out of ideas.

4. Ask students what they want to find out or to learn about the topic. The teacher and student record these questions in the $\mathrm{W}$ column of their charts. This is done until students run out of ideas for question. If students respond with statement, turn them into question before recording them in the $\mathrm{W}$ column.

5. Have students read the text and fill out the L column on their chart. Students should look for the answers to the questions in their W column while they are reading. Students can fill out their L column either during or after reading.

\section{4) Conceptual Framework}

Teaching is an activity to make an interaction between teacher and students. In teaching process the teacher shared her/his knowledge to the students, it means that the teacher help the students to understand or to know something.

Reading is a subject that is most important to learn. Reading is the process to understand a text. In reading process there is an interaction between the reader and the writer. Here, the reader learn that what the purpose of the writer in the text. What the writer would share and the reader learn what the new information from the text.

Most of the students have difficulties in getting information from the text. The students do not know the topic of the text. They feel difficult to understand the paragraph they have read. When teacher ask the students answering some questions, they cannot answer.

To make students understand the text, a teacher should teach them with some strategies and the teacher chooses one of the suitable text to make easy to understand.

One of the suitable strategies is K-W-L (Know-What-Learn). K-W-L is an instruction reading strategy that is used to guide students through a text. Students begin brainstorming everything they know about a topic. This information is recorded in the K column of a KWL chart. Students than generate a list of question about what they want to know about the topic. These questions are listed in the $\mathrm{W}$ column of the chart. During or after reading students answer the

questions are listed in the $\mathrm{W}$ column. This new information that they have learned is recorded in $\mathrm{L}$ column of the KWL chart. K-W-L as one of technique in teaching reading, can be use to increase students reading comprehension. 


\section{Research Design}

Experimental research was conducted in this study. To collect the data, two groups were used. They were experimental group and control groups. The variables were examined in this study, they were K-W-L strategy, reading as independent variable and students' reading comprehension as dependent variable. The experimental group was the group that received the treatment by teaching K-W-L strategy, and the control group is the group that received treatment by using conventional method.

Table 2.1 Research design

\begin{tabular}{|l|l|l|l|}
\hline Experimental group & Pre-test & $\begin{array}{l}\text { Have treatment } \\
\text { (K-W-L strategy Reading) }\end{array}$ & Post-test \\
\hline Control Group & Pre-test & $\begin{array}{l}\text { Without treatment } \\
\text { (Conventional strategy) }\end{array}$ & Post-test \\
\hline
\end{tabular}

1) Population and Sample

The population of this research was the fifth semester students of Faculty of Education of HKBP Nommensen University. There were 46 students in the class and it was divided into two groups, group A and group B, each group consisted of 23 students, group A was as an Experimental Group and Group B as a Control Group

\section{2) The Instrument of Collecting the Data}

In this study, the writer used a test as the instrument to obtain the data. The data was collected by giving a multiple choise test which consists of twenty five items. It was given to both, experimental and control group in pre-test and post-test. The time given was 40 minutes. Student used the time effectively to finish the test.

\section{3) The Procedure of Collecting the Data}

The procedure in collecting the data was divided into three steps, namely: pre-test, treatment, and post-test.

\section{(1) Pre-test}

First of all the researcher explained about the research. Both of the experimental and control group were given a pre-test before doing treatment for the experimental group. The result of the group should be different.

\section{(2) Treatment}

After the pre-test, the researcher gave treatment for the students through teaching K-W-L strategy, while the control group without treatment. 
Table 2.2 Teaching procedure

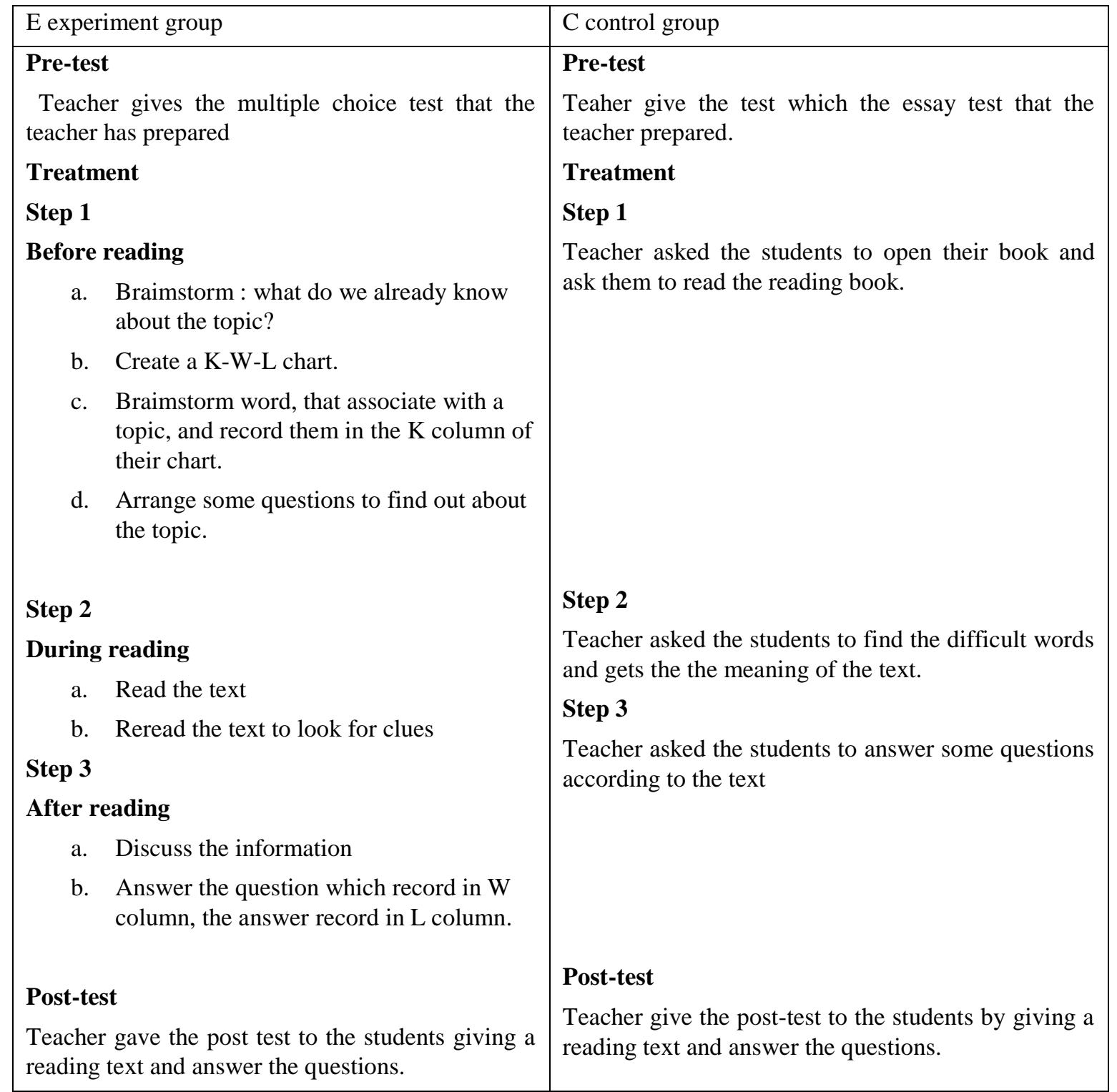

(3) Post-test

Post-test was given to know the different score between the experimental and the control group. The post -test was given after the treatment was completed and it was used to find out the differences mean of the experimental and control group.

\section{4) Scoring the test}

For scoring the test, the writer used the way to score the multuple choises :

$$
\mathrm{S}=\frac{R}{N} \mathrm{X} 100 \%
$$

Where :

$\mathrm{S}=$ Score number of the test

$\mathrm{R}=$ Number of the correct answers

$\mathrm{N}=$ Number of the question 


\section{(1) The Validity of the Test}

Validity refers to the extent to which an instrument measures what it is intended to measure. The validity question is concerned with the extent to which an instrument measures what one thinks it is measuring. This study applied content validity to the test. Content validity of the test must show that the test could represent the curriculum which covered all the materials and the objectives which is obtained by the students.

\section{(2) The Reliability of the Test}

Reliability is the extent to which a measuring device is consistent in measuring whatever it measures. A test must be consistent and reliable. The test uses Kuder Richardson formula 21 as follows:

$$
\mathrm{R}=\frac{K}{K-1}\left[1-\frac{M(K-M)}{K S^{2}}\right]
$$

In which:

$$
\begin{aligned}
& \mathrm{K}=\text { the number of Questions } \\
& \mathrm{M}=\text { the mean of test score } \\
& \mathrm{S}=\text { the standard deviation }
\end{aligned}
$$

According to Sugiono ( 2009 :257) the categories of coefficient correlations are as the following :

$0,00-0,199=$ the reliability is very low

$0,20-0,399=$ the reliability is low

$0,40-0,599=$ the reliability is fair

$0,60-0,799=$ the riliability is high

$0,80-1,000=$ the reliability is very high

\section{The Technique of Analyzing Data}

In this study, the data was obtained from the experimental group and the control group. To know the difference between the groups, the data was analyzed by using the $t$-test formula as following:

$$
\mathrm{t}=\frac{M x-M y}{\sqrt{\left(\frac{\sum X^{2}+\sum Y^{2}}{N x+N y-2}\right)\left(\frac{1}{N x}+\frac{1}{N y}\right)}}
$$

Where:

$$
\begin{array}{ll}
\mathrm{T} & =\text { Total score } \\
\mathrm{Mx} & =\text { Mean of experimental group } \\
\mathrm{My} & =\text { Mean of control group } \\
\mathrm{Nx} & =\text { Numbers of students in experimental group } \\
\mathrm{Ny} & =\text { Numbers of students in control group } \\
\mathrm{x}^{2} & =\text { Standard of Deviation of experimental group } \\
\mathrm{y}^{2} & =\text { Standard Deviation of Control group }
\end{array}
$$

\section{1) The Procedure of Analyzing the Data}

1. Collecting the data from the score of both groups.

2. Identifying the score of the students who were being treated and who were not.

3. Comparing the score.

4. Analysing the data

5. Drawing the conclusion and answering the hypothesis.

6. Writing some findings.

\section{2) Statistical Hypothesis}

Based on the hypothesis, it could be transformed into statistical hypothesis. This statistical hypothesis was tested as follows: 
$\mathrm{H}_{\mathrm{o}} \quad=\mu . \mathrm{X} 1=\mu . \mathrm{X} 2$

$\mathrm{H}_{\mathrm{a}}=\mu . \mathrm{X} 1>\mu . \mathrm{X} 2$

Where :

$$
\begin{array}{ll}
\mathrm{H}_{\mathrm{o}} & =\text { Null hypothesis } \\
\mathrm{H}_{\mathrm{a}} & =\text { Alternative hypothesis } \\
\mu & =\text { The meana of all students } \\
\mathrm{X} 1 & =\text { The means of students taught by using KWL } \\
\mathrm{X} 2 & =\text { The means of students taught by conventional method3) Data }
\end{array}
$$

\begin{tabular}{|c|c|c|c|}
\hline No & INITIAL STUDENTS' NAME & $\begin{array}{l}\text { Pre- Test } \\
\text { (X1) }\end{array}$ & $\begin{array}{l}\text { Post - Test } \\
\text { ( X2 ) }\end{array}$ \\
\hline 1 & $\mathrm{RG}$ & 50 & 65 \\
\hline 2 & DVS & 60 & 75 \\
\hline 3 & DJL & 65 & 77 \\
\hline 4 & MS & 70 & 80 \\
\hline 5 & RP & 45 & 65 \\
\hline 6 & IRT & 60 & 75 \\
\hline 7 & SS & 60 & 77 \\
\hline 8 & RRS & 55 & 80 \\
\hline 9 & NBS & 60 & 65 \\
\hline 10 & CHP & 55 & 75 \\
\hline 11 & MSG & 70 & 75 \\
\hline 12 & GLTN & 70 & 70 \\
\hline 13 & RSM & 60 & 80 \\
\hline 14 & $\mathrm{DH}$ & 55 & 75 \\
\hline 15 & MP & 65 & 85 \\
\hline 16 & TS & 55 & 88 \\
\hline 17 & $\mathrm{RP}$ & 75 & 75 \\
\hline 18 & $\overline{\mathrm{DF}}$ & 60 & 70 \\
\hline 19 & SBG & 60 & 80 \\
\hline 20 & MRS & 68 & 75 \\
\hline 21 & SYM & 73 & 85 \\
\hline 22 & PMD & 67 & 80 \\
\hline 23 & RSN & 68 & 75 \\
\hline \multicolumn{2}{|r|}{ Total } & 1426 & 1893 \\
\hline & Mean & 62 & 82,30 \\
\hline
\end{tabular}

The writer gained the students' score after applying the post-test to the experimental and control group.

Table 3.1 The score of the Experimental group

In the experimental group, the lowest score for pre-test is 48 and the highes is 76 , while the lowest score for the post-test is 60 and the highes is 92 . 
Furthermore, In the control group, the lowest score for the pre-test is 44 and the highest is 76 while the lowest score for the post-test is 52 and the highest score is 84 .

Table 3.2 The score of the Control group

\begin{tabular}{|c|c|c|c|}
\hline No & INITIAL STUDENTS' NAME & $\begin{array}{l}\text { Pre- Test } \\
\text { (Y1) }\end{array}$ & $\begin{array}{l}\text { Post - Test } \\
\text { ( Y2) }\end{array}$ \\
\hline 1 & $\mathrm{CPH}$ & 60 & 64 \\
\hline 2 & SPM & 55 & 55 \\
\hline 3 & DTH & 50 & 56 \\
\hline 4 & KLO & 65 & 70 \\
\hline 5 & JKM & 70 & 72 \\
\hline 6 & SFD & 65 & 68 \\
\hline 7 & HJ & 60 & 65 \\
\hline 8 & WR & 54 & 60 \\
\hline 9 & AGH & 52 & 55 \\
\hline 10 & SSG & 60 & 55 \\
\hline 11 & EGH & 65 & 65 \\
\hline 12 & WFK & 60 & 65 \\
\hline 13 & SR & 55 & 60 \\
\hline 14 & TY & 50 & 55 \\
\hline 15 & WES & 60 & 60 \\
\hline 16 & LY & 66 & 64 \\
\hline 17 & QUI & 54 & 68 \\
\hline 18 & AVB & 52 & 56 \\
\hline 19 & ZHJ & 60 & 55 \\
\hline 20 & RTS & 65 & 63 \\
\hline 21 & BCS & 56 & 65 \\
\hline 22 & AMK & 55 & 60 \\
\hline 23 & NYP & 65 & 58 \\
\hline & Total & 1354 & 1414 \\
\hline & Mean & 58,86 & 61,47 \\
\hline
\end{tabular}

\section{Data Analysis}

Based on the ability of the students, students who got the score $80-100$ is categorized as a very good, 60-79 is categorized good, and 0-59 is categorized as poor.

It can be concluded that the students in the experiment could be categorized as good because they were taught by using Know-Want -Learned ( KWL) in reading comprehension. It means that after applying KWL, most of them could answer the questions well. In fact, when students were taught by applying KWL, they can increase their achievement in reading comprehension through motivation and development of background,asking knowledge, strategy or skill building activities, and enrichment activities. As consequence, most students can elicit prior knowledge and find specific information from the reading text. Most students were active in the class when there was teaching learning process. It means that the score of te student in the post-test was better than the pre-test. 
Table 4.1 The calculation of the experimental group

\begin{tabular}{|c|c|c|c|c|c|c|c|}
\hline \multirow[t]{2}{*}{ NO } & \multirow[t]{2}{*}{$\begin{array}{l}\text { Initial } \\
\text { name }\end{array}$} & \multirow{2}{*}{$\begin{array}{l}\text { Pre-test } \\
\\
\text { X1 }\end{array}$} & \multirow{2}{*}{$\begin{array}{l}\text { Post-test } \\
\\
\text { X2 }\end{array}$} & deviation & \multirow{2}{*}{$\begin{array}{l}\text { Square of } \\
\text { deviation }\end{array}$} & \multirow[t]{2}{*}{$\begin{array}{l}\mathbf{D}-\mathbf{M x} \\
(\mathbf{X})\end{array}$} & \multirow[t]{2}{*}{$\begin{array}{l}D x^{2} \\
\left(X^{2}\right)\end{array}$} \\
\hline & & & & $\begin{array}{l}\mathrm{d}=\mathrm{X} 2 \\
\mathrm{X} 1\end{array}$ & & & \\
\hline 1 & $\mathrm{RG}$ & 50 & 65 & 15 & 225 & 0,61 & 0,37 \\
\hline 2 & DVS & 60 & 75 & 15 & 225 & 0,61 & 0,37 \\
\hline 3 & DJL & 65 & 77 & 12 & 144 & $-2,39$ & 5,61 \\
\hline 4 & $\mathrm{MS}$ & 70 & 80 & 10 & 100 & $-4,39$ & 19,27 \\
\hline 5 & RP & 45 & 65 & 20 & 400 & 5,61 & 31,47 \\
\hline 6 & IRT & 60 & 75 & 15 & 225 & 0,61 & 0,31 \\
\hline 7 & $\mathrm{SS}$ & 60 & 77 & 17 & 289 & 2,61 & 6,81 \\
\hline 8 & RRS & 55 & 80 & 35 & 1225 & 20,61 & 424,77 \\
\hline 9 & NBS & 60 & 65 & 5 & 25 & $-9,39$ & 88,17 \\
\hline 10 & CHP & 55 & 75 & 20 & 400 & 5,61 & 31,47 \\
\hline 11 & MSG & 70 & 75 & 5 & 25 & $-9,39$ & 88,17 \\
\hline 12 & GLTN & 70 & 70 & 0 & 0 & $-14,39$ & 207,07 \\
\hline 13 & RSM & 60 & 80 & 20 & 400 & 25,61 & 1347,34 \\
\hline 14 & $\mathrm{DH}$ & 55 & 75 & 20 & 400 & 25,61 & 1347,34 \\
\hline 15 & MP & 65 & 85 & 20 & 400 & 25,61 & 1347,34 \\
\hline 16 & TS & 55 & 88 & 33 & 1085 & 18,61 & 346,33 \\
\hline 17 & $\mathrm{RP}$ & 75 & 75 & 0 & 0 & $-14,39$ & 207,07 \\
\hline 18 & DF & 60 & 70 & 10 & 100 & $-4,39$ & 19,27 \\
\hline 19 & SBG & 60 & 80 & 20 & 800 & 5,61 & 31,47 \\
\hline 20 & MRS & 68 & 75 & 7 & 49 & $-7,39$ & 54,61 \\
\hline 21 & SYM & 73 & 85 & 12 & 144 & $-2,39$ & 5,71 \\
\hline 22 & PMD & 67 & 80 & 13 & 169 & $-1,39$ & 1,93 \\
\hline 23 & RSN & 68 & 75 & 7 & 49 & $-7,39$ & 54,61 \\
\hline & Total & 1426 & 1893 & 331 & 5879 & 8,81 & 5648,88 \\
\hline & Mean & 62 & 82,30 & 14,39 & 255,60 & 0,38 & 245,60 \\
\hline
\end{tabular}

$$
\begin{aligned}
& \mathrm{Mx}=\frac{\sum X}{N} \\
& \mathrm{Mx}=\frac{331}{23} \\
& \mathrm{Mx}=14,39
\end{aligned}
$$


Table 4.2 The Calculation of the control group

\begin{tabular}{|c|c|c|c|c|c|c|c|}
\hline \multirow[b]{2}{*}{ NO } & \multirow[t]{2}{*}{$\begin{array}{l}\text { Initial } \\
\text { name }\end{array}$} & \multirow{2}{*}{$\begin{array}{l}\text { Pre-test } \\
\text { Y1 }\end{array}$} & \multirow{2}{*}{$\begin{array}{l}\text { Post-test } \\
\text { Y2 }\end{array}$} & Deviation & \multirow{2}{*}{$\begin{array}{l}\begin{array}{l}\text { Square of } \\
\text { deviation }\end{array} \\
\mathbf{d}^{2}\end{array}$} & \multirow[t]{2}{*}{$\begin{array}{l}\text { d-My } \\
(\text { Y) }\end{array}$} & \multirow[t]{2}{*}{$\begin{array}{l}d y^{2} \\
\left(Y^{2}\right)\end{array}$} \\
\hline & & & & $\begin{array}{l}\mathrm{d}=\mathrm{Y2} \\
\mathbf{Y 1}\end{array}$ & & & \\
\hline 1 & $\mathrm{CPH}$ & 60 & 64 & 4 & 16 & 1,35 & 1,82 \\
\hline 2 & SPM & 55 & 55 & 0 & 0 & $-2,65$ & 7,02 \\
\hline 3 & DTH & 50 & 56 & 6 & 36 & 3,35 & 11,22 \\
\hline 4 & $\mathrm{KLO}$ & 65 & 70 & 15 & 225 & 12,35 & 152,52 \\
\hline 5 & JKM & 70 & 72 & 2 & 4 & $-0,65$ & 0,42 \\
\hline 6 & SFD & 65 & 68 & 3 & 9 & 0,35 & 0,12 \\
\hline 7 & HJ & 60 & 65 & 5 & 25 & 2,35 & 5,52 \\
\hline 8 & WR & 54 & 60 & 6 & 36 & 3.35 & 11,22 \\
\hline 9 & $\mathrm{AGH}$ & 52 & 55 & 3 & 9 & 0,35 & 0,12 \\
\hline 10 & $\mathrm{SSG}$ & 60 & 55 & -5 & 25 & $-7,65$ & 58,52 \\
\hline 11 & $\mathrm{EGH}$ & 65 & 65 & 0 & 0 & $-2,65$ & 7,02 \\
\hline 12 & WFK & 60 & 65 & 5 & 25 & 2,35 & 5,52 \\
\hline 13 & SR & 55 & 60 & 5 & 25 & 2,35 & 5,52 \\
\hline 14 & TY & 50 & 55 & 5 & 25 & 2,35 & 5,52 \\
\hline 15 & WES & 60 & 60 & 0 & 0 & $-2,65$ & $-5,3$ \\
\hline 16 & LY & 66 & 64 & -2 & 4 & $-4,65$ & 21,62 \\
\hline 17 & QUI & 54 & 68 & 6 & 36 & 3,35 & 11,22 \\
\hline 18 & AVB & 52 & 56 & 4 & 16 & 1,35 & 1,82 \\
\hline 19 & ZHJ & 60 & 55 & -5 & 25 & $-7,65$ & 58,52 \\
\hline 20 & RTS & 65 & 63 & -2 & 4 & $-4,65$ & 21,62 \\
\hline 21 & $\mathrm{BCS}$ & 56 & 65 & 9 & 81 & 6,35 & 40,32 \\
\hline 22 & AMK & 55 & 60 & 5 & 25 & 2,35 & 5,52 \\
\hline 23 & NYP & 65 & 58 & -7 & 49 & $-9,65$ & 93,12 \\
\hline & Total & 1354 & 1414 & 61 & 700 & 1,05 & 510,52 \\
\hline & Mean & 58,86 & 61,47 & 2,65 & 30,43 & 0,04 & 22,19 \\
\hline
\end{tabular}

$$
\begin{aligned}
& \text { My }=\frac{\sum Y}{N} \\
& \text { My }=\frac{61}{23} \\
& \text { My }=2,65
\end{aligned}
$$

From the data, it can be explained that students in the control group can be categorized poor because they could not answer the questions well eventhough, they had been taught by using dictionary. In this case, the score of the students in the pre-test could be lower in the post-test or contrarily, the score in the pre-test could be increased in the post-test. Therefore, the score of the students in post-test was not better than pre-test.

From the analysis of the result, it can be concluded that applying KWL in reading comprehension can help the students to promote critical thinking about what they read because this strategy can involve the students and make 
them more active in the clss. In other words, by apllying KWL in teaching reading comprehension can improve the students' reading achievement.

\section{1) Realibility of the Test}

The data obtained from try out was analyzed to find out the realibility of the test. To get the realibilty of the test, the Kuder-Richardson 21 Formula ( KR21) was applied. The formula was applied on the try out test. It was tested on the group which was out of control group and experimetal group, but they had a same number of samples ( 20 samples)

$$
\mathbf{r}=\frac{K}{K-1}\left[1-\frac{M(K-M)}{K S^{2}}\right]
$$

In Which:

$\mathrm{K}=25$

$\mathrm{M}=16,05$

$\mathrm{S}=6,10$

Table 4.3 The Try Out Score

\begin{tabular}{|c|c|c|c|}
\hline NO & STUDENTS INITIAL NAME & SCORE ( X ) & $\operatorname{SCORE}^{2}\left(\mathrm{X}^{2}\right)$ \\
\hline 1 & TP & 18 & 324 \\
\hline 2 & $\mathrm{RF}$ & 12 & 144 \\
\hline 3 & RN & 14 & 196 \\
\hline 4 & RVB & 16 & 256 \\
\hline 5 & $\mathrm{JH}$ & 11 & 121 \\
\hline 6 & WIB & 16 & 256 \\
\hline 7 & AA & 17 & 289 \\
\hline 8 & RW & 15 & 225 \\
\hline 9 & DB & 20 & 400 \\
\hline 10 & AS & 20 & 400 \\
\hline 11 & GG & 18 & 324 \\
\hline 12 & EJG & 16 & 256 \\
\hline 13 & RS & 12 & 144 \\
\hline 14 & ESS & 14 & 196 \\
\hline 15 & DG & 18 & 324 \\
\hline 16 & FT & 16 & 256 \\
\hline 17 & ILB & 17 & 289 \\
\hline 18 & MCB & 19 & 361 \\
\hline 19 & DT & 15 & 225 \\
\hline 20 & EN & 17 & 289 \\
\hline & TOTAL & 321 & 5275 \\
\hline & MEAN & 16,05 & \\
\hline
\end{tabular}

\section{2) The calculation of realiability of he test}

$$
\begin{aligned}
& \mathrm{M}=\frac{\sum X}{N} \\
& \mathrm{M}=\frac{321}{38}
\end{aligned}
$$




$$
\begin{aligned}
& \mathrm{M}=16,05 \\
& \mathrm{~S}=\frac{\sum X^{2}-\left(\frac{\sum X}{N}\right)^{2}}{N} \\
& \mathrm{~S}=\frac{5275-\left(\frac{321}{20}\right)^{2}}{20} \\
& \mathrm{~S}=\frac{5275-\left(\frac{10304}{20}\right)^{2}}{20} \\
& \mathrm{~S}=\frac{5275-5152,05}{20} \\
& \mathrm{~S}=\frac{122,95}{20} \\
& \mathrm{~S}=6,14 \\
& \mathrm{r}=\frac{K}{K-1}\left[1-\frac{M(K-M)}{K S^{2}}\right] \\
& \mathrm{r}=\frac{25}{25-1}\left(1-\frac{16,05(25-16,05)}{25(6,14)^{2}}\right) \\
& \mathrm{r}=\frac{25}{24}\left(1-\frac{143,64}{25(37,69)}\right) \\
& \mathrm{r}=1.04\left(1-\frac{143,64}{943,25}\right) \\
& \mathrm{r}=1,04 \times(1-0,15) \\
& \mathrm{r}=1,04 \times 0,85 \\
& \mathrm{r}=0,88
\end{aligned}
$$

It was obtained that he realibility of the tets was 0.88 . it showed that the test was reliable because the value of the realibility of the test had high coefficient correlation based on the theories.

\section{3) Testing Hypothesis}

$\mathrm{T}$ - test formula was used to test the hypothesis. From the data, it was obtained that :

$\mathrm{Mx}=10,94$

$\sum X^{2}=1077,76$

$\mathrm{Nx}=38$

$\mathrm{My}=7,05$

$\sum Y^{2}=685,80$

$\mathrm{Ny}=38$

The formula for computing the t-test is as following

$$
\begin{aligned}
& \mathrm{t}=\frac{M x-M y}{\sqrt{\left(\frac{\sum X^{2}+\sum Y^{2}}{N x+N y-2}\right)\left(\frac{1}{N x}+\frac{1}{N y}\right)}} \\
& \mathrm{t}=\frac{10,94-7,05}{\sqrt{\left(\frac{1077,76+685,80}{38+38-2}\right)\left(\frac{1}{38}+\frac{1}{38}\right)}} \\
& \mathrm{t}=\frac{3,89}{\sqrt{\left(\frac{1763,56}{74}\right)\left(\frac{2}{38}\right)}} \\
& \mathrm{t}=\frac{3,89}{\sqrt{(23,83)(0,05)}} \\
& \mathrm{t}=\frac{3,89}{\sqrt{1,19}} \\
& \mathrm{t}=\frac{3,89}{1,09} \\
& \mathrm{t}=\mathbf{3 , 5 6}
\end{aligned}
$$


From the criteria of the hypothesis, $\mathrm{H}_{\mathrm{a}}$ was accepted if $\mathrm{t}_{\text {observed }}>\mathrm{t}$ table. From the calculation above, it was found that $\mathrm{t}$ observed was higher than $\mathrm{t}_{\text {table }} \quad(3,56>1,992)$. It meant that $\mathrm{H}_{\mathrm{a}}$ hypothesis was accepted thelevel of significance 0,05 and the degree of freedom $(\mathrm{df})=\mathrm{Nx}+\mathrm{Ny}-2=74$.

\section{4) Research Finding}

The data obtained from the experimental group and the score of the control group were analyzed by applying t-test formula and it was found that students' achievement who were taught by applying KWL was higher than those who were taught without applying KWL.

1. The data obtained that the ability of fifth semester students were taught by KWL was good and effective, and the score of the experimental group and the score of the control group were analyzed by applying t-test formula and it was found that students' achievement who were taught by applying KWL was higher than those who were taught without applying KWL.

2. When doing treatment in four meetings to the experimental group the students were active and the score in the post-test of the test, they got higher than score in the pre-test. The researcher thought that, if KWL used in teaching reading more than fourth, would be increase the students' reading comprehension.

It means that the application of Know- Want-Learn technique significantly affects on students' reading comprehension.

\section{Conclusion}

Based on the result of the study, the conclusions are drawn as follows :

1) The mean score of the students who were taught by applying Know - Want - Learn technique ( K-W- L) $(73,36)$ is higher than mean score of students who were tauhgt without applying K-W-L $(68,73)$

2) The $t_{\text {observed }}(3,56)$ is higher than table $(1,992)$ at the level of significance of 0,05 of two-tailed test. It mens that $\mathrm{H}_{\mathrm{a}}$ is accepted. Thus, it can be concluded that there is a significant effect of applying Know-Want -Learn on students' reading comprehension.

\section{Suggestion}

Based on the conclusion drawn above, it is suggested that :

1. English teachers are suggested to use K-W-L technique at collage level in a teaching- learning process in order to improve the students' reading achievement in comprehend the text.

2. Students can be guided to applying K-W-L to reach their achievement in reading a text and enrich their knowledge.

\section{References}

Best W.John \& Khan V.James. (2002). Research in education. Prentice-Hall of India.Private limited: New Delhi.

Best. W. John \& Khan. V. James. (2002). Research in Education . $7^{\text {th }}$ New Delhi: Prentice-Hall.

Burns C.Paul, Roe D. Betty \& Ross P.Elinor. (1984). Teaching reading in today's elementary school $3^{\text {rd }}$. New York: Houghton Miffin.

Burns, C.Paul. et.al. (1984). Teaching Reading in Today's Elementary Schools. $3^{\text {rd }}$.Ed. Boston: Houghton Mifflin Company.

Cadlin, N. Christoper \& Hall, R David. (2002). Teaching and Researching Reading. White Plain :Pearson Education.

Callahan F.Joseph \& Clark H.Leonard. (1988). Teaching in the middle and secondary schools $3^{\text {rd }}$. New York: macmillan.

David, C. (1979). Learning strategies resource guide, Florida: Region XIV Comprehension Center, pp 11-14.

Dyer Jean Royer. Understanding and Evaluating Educational Research. London: Addison-Wesley Publishing Company.

Heilman W.Arthur, Blair R.Timothy \& Rupley H.William. (1986). Principles and practices of teaching reading $5^{\text {th }}$. Ohio: Bell and Howell.

Heilman, W. Athur.et.al. Principles and Practice of Teaching Reading. $5^{\text {th }}$. Ed. Bell \& Howell Company.

Kustaryo, Sukirah. (1998). Reading Techniques for college students. DEPDIKBUD. 
Michael Susan. (2006). KWL - A Reading comprehension strategy. Available in http://www.indiana.edu. 1517/KWL.htm

O’Donoghue Tom \& Punch Keith. (2003). Qualitative Educational Research in Action. London and New York: RoutledgeFalmer.

Richard A.Patrcia. (1981). Academic success for English language learners. New York. Longman.

Richards, C. Jack \& Rodgers, S. Theodore. (2001). Approach and Methods in Language Teaching. $2^{\text {nd }}$ Ed. Cambridge University Press. http://dx.doi.org/10.1017/CBO9780511667305

Sagala H. Syaiful DR. (2008). Konsepdanmaknapembelajaran. Bandung: Alfabeta.

Setiyadi, Ag. Bambang. (2006). Teaching English as a Foreign Language. Yogyakarta: GrahaIlmu.

Sugiono, Dr. Prof. (2009). Metode penelitian pendidikan pendekatan,kuantitatif,kualitatif, dan R dan D. Bandung : Alfabeta.

Suharsini, Arikunto. (2006). ProsedurPenelitiansuatupendekatanpraktik. Jakarta: RinekeCipta.

SuharsiniArikunto Prof.DR. (2006). Procedure Penelitianpendidikan: RhinekaCipta:Jakarta.

SukirahKustary, (1988). Reading techniques for college students: DEPDIKBUD.

Wallace, J. Michael. (1998). Action Research for Language Teachers. United Kingdom: Cambridge University Press. 